\title{
PENGARUH COUNTRY OF ORIGIN DAN BRAND IMAGE TERHADAP KEPUTUSAN PEMBELIAN SMARTPHONE DI UNIVERSITAS BORNEO TARAKAN (STUDI KASUS PADA MAHASISWA UNIVERSITAS BORNEO TARAKAN)
}

\author{
THE EFFECT COUNTRY OF ORIGIN AND BRAND IMAGE \\ ON SMARTPHONE PURCHASING DECISION AT UNIVERSITY OF BORNEO \\ TARAKAN (A CASE STUDY OF UNIVERSITY OF BORNEO TARAKAN)
}

\author{
Yugi Pratama ${ }^{1)}$, Nurjannatul Hasanah ${ }^{2)}$ \\ (Universitas Borneo Tarakan)
}

\begin{abstract}
Abstrak: Penelitian ini bertujuan untuk mengetahui pengaruh: Country of Origin dan Brand Image terhadap Keputusan Pembelian Smartphone di Universitas Borneo Tarakan (Studi Kasus Pada Mahasiswa Universitas Borneo Tarakan) Dimana diajukan dua variabel bebas dan satu variabel terikat, yaitu Country of Origin dan Brand Image berperan sebagai variabel bebas dan Keputusan Pembelian sebagai variabel terikat. Metode sampel yang digunakan dalam penelitian ini adalah Nonprobability Sampling dengan teknik pengambilan sampel yaitu menggunakan Purposive Sampling. Data diperoleh dari hasil penyebaran Kuesioner dengan jumlah Kuesioner 100 buah Kuesioner. Metode analisis dalam penelitian ini menggunakan analisis regresi linier berganda. Pengujian statistik dalam penelitian ini menggunakan uji $t$. Hasil penelitian ini adalah dalam pengujian secara parsial variabel Country of Origin tidak berpengaruh secara signifikan terhadap Keputusan Pembelian.Varibel Country of Origin $t$ hitung $=-1.230<t$ tabel $=1,661, t$ hitung lebih rendah dari $t$ tabel. Sedangkan Brand Image t hitung 6,152 > t tabel 1,661, berpengarus secara signifikan karena $t$ hitung lebih tinggi dari pada t tabel yang di persyaratkan. Dari hasil pengolahan data secara pasrial dalam penelitian ini menunjukkan bahwa dari ke dua variabel bebas hanya satu variabel bebas yang berpengaruh secara positif dan signifikan yaitu variabel Brand Image terhadap variabel terikat Keputusan pembelian.
\end{abstract}

Kata kunci : Country of Origin, Brand Image, Keputusan Pembelian

Abstract: Smartphone Purchasing Decision at University of Borneo Tarakan (A Case Study of University of Borneo Tarakan) Where the proposed two independent variables and one dependent variable, Country of Origin and Brand Image act as independent variable And Purchase Decision as the dependent variable. Sample method used in this research is Nonprobability Sampling with sampling technique using Purposive Sampling. Data obtained from the results of the distribution of questionnaires, which amounted to 100 pieces of questionnaires. The method of analysis in this study using multiple linear regression analysis. Test statistic in this research use t test. The result of this research is in partial test of Country of Origin variable has no significant effect on Purchasing Decision. Variable Country of Origin $t$ arithmetic $=-1.230<t$ table $=1.661, t$ arithmetic lower than $t$ table. While Brand Image $t$ arithmetic 6.152> t table 1.661, significantly significant because t arithmetic higher than $t$ table in the requirement. From the results of data processing in pasrial in this study showed that from the two independent variables only one independent variable that influenced positively and significantly is the Brand Image variable to the dependent variable purchase decision.

Keywords: Country of Origin, Brand Image, Purchase Decision 


\section{LATAR BELAKANG}

Dengan kemajuan teknologi yang semakin pesat. Manusia diberikan kemudahan dalam menjalani aktivitasnya sehari-hari. Salah satu teknologi yang memudahkan aktivitas manusia adalah Telpon Pintar atau yang biasa kita sebut sebagai Smartphone.

Smartphone memudahkan manusia untuk berkomunikasi jarak jauh, dan mengirim pesan singkat bukan saja berkomunikasi dan mengirim pesan singkat seiring perkembangan zaman Smartphone dilengkapi dengan teknologi-teknologi canggih seperti adanya camera yang tidak hanya digunakan menggambil gambar tetapi juga bisa digunakan untuk merekam video, serta jaringan internet yang semakin lama dapat diakses dengan mudah melalui Smartphone seperti aplikasi permainan, sosial media, dan lainya semakin mudah di akses dengan menggunakan Smartphone, tidak hanya itu Smartphone juga bisa digunakan untuk meyimpan file layaknya sebuah komputer.

Dengan adanya ketertarikan konsumen terhadap Smartphone, perusahanperusahaan Smartphone semakin ketat dalam persaingan penjualan smartphone, perusahaan dituntut untuk menciptakan smartphone yang berkualitas dan berteknologi cangih serta desain yang menarik dan harga yang sesuai dengan pasar yang dituju.

Smartphone diluncurkan untuk pertama kalinya pada tahun 1992 dan hingga saat ini perkembangannya memiliki banyak perubahan yang selalu meningkat. Smartphone memiliki segmentasi yang berbedabeda, di Indonesia itu sendiri Smartphone dikelompokkan menjadi 3 kelas berdasarkan level harga dan spesifikasinya, yaitu :

(wikipedia.com).

1. Ponsel cerdas kelas atas (highend).

2. Ponsel cerdas kelas menengah (middle level).

3. Ponsel cerdas kelas bawah (entry level).
Dibandingkan dengan negara di Asia Tenggara lainnya, seperti Vietnam dan Thailand, prestasi keduanya mengekor di belakang Indonesia dengan pertumbuhan pasar masing-masing 59 dan 45 persen per tahun. Total Smartphone yang terjual di Tanah Air mencapai 7,3 juta unit, atau dua per lima dari jumlah total penjualan di Asia Tenggara (tekno.kompas.com).

Sebelum menentukan produk apa yang akan dibeli, untuk sebagian konsumen akan melihat dari mana negara asal produk tersebut diproduksi. Negara yang menjadi tempat asal suatu produk disebut dengan istilah Country of Origin yang secara umum dianggap sebagai bagian dari karakteristik suatu produk (Cordell, 1992 ; Hong and Wyer, 1989). Negara yang menjadi tempat asal suatu produk akan menimbulkan persepsi akan kualitas baik buruknya tentang suatu produk.

Country of Origin secara umum dianggap menjadi karakteristik suatu produk. Country of Origin dapat mempengaruhi konsumen dalam mengevaluasi produk untuk pengambilan suatu keputusan dan sebagai gambaran umum yang mungkin dapat mempengaruhi konsumen. Menurut (Abdi, 2009) Country of Origin merupakan identitas dalam atribut produk yang mempengaruhi evaluasi konsumen dalam mengidentifikasi asal negara suatu produk. Pada perilaku pembelian dalam Keputusan Pembelian, konsumen dapat menentukan keberhasilan strategi perusahaan di dalam negeri dan pasar luar negeri.

Aspek lain yang sering kali dijadikan acuan adalah dengan melihat Brand Image suatu produk. Brand atau merek muncul sebagai alat untuk menguasai pasar. Peran brand sendiri adalah untuk memudahkan identifikasi suatu produk, atau dengan kata lain sebagai pembeda antara produk yang satu dengan yang lain. Adapun peran lainnya adalah membantu menciptakan loyalitas, membantu targeting dan positioning suatu produk. Mempertahankan eksistensi dan kesuksesan sebuah brand adalah sebuah tantangan yang harus dihadapi oleh para pemasar produk mengingat persaingan bisnis 
yang makin ketat saat ini. Era globalisasi saat ini pun menuntut para produsen Smartphone untuk lebih kreatif dalam menanamkan loyalitas terhadap konsumen (dalam Kitto Hananto, 2015).

Brand Image merupakan syarat dari merek yang kuat. Reputasi merek akan memengaruhi pandangan seseorang terhadap produk yang ditawarkan oleh para produsen. Brand Image merupakan seperangkat keyakinan, ide, kesan yang dimiliki sesorang terhadap suatu merek (Simamora, 2004). Apabila para konsumen beranggapan bahwa merek tertentu secara fisik berbeda dari merek pesaing citra merek tersebut akan melekat secara terus-menerus sehingga dapat menciptakan loyalitas konsumen (Rangkuti, 2004).

Dengan kata lain, Brand Image merupakan salah satu unsur penting yang dapat mendorong konsumen untuk membeli produk. Semakin baik Brand Image yang melekat pada produk maka konsumen akan semakin tertarik untuk membeli produk tersebut. Brand Image memiliki tiga variabel pendukung yaitu Citra Pembuat (Corporate Image), Citra Pemakai (User Image), dan Citra Produk (Product Image). Corporate Image merupakan sekumpulan asosiasi yang dipersepsikan konsumen terhadap perusahaan yang membuat suatu produk atau jasa dimana indikatornya meliputi nama besar perusahaan, layanan perusahaan dan jaringan perusahaan. User Image merupakan sekumpulan asosiasi yang

dipersepsikan konsumen terhadap pemakai yang menggunakan suatu barang atau jasa, indikatornya yaitu gaya, gaul, percaya diri, dan mewah.

Variabel yang terakhir yaitu Product Image yaitu sekumpulan asosiasi yang dipersepsikan konsumen terhadap suatu produk (dalam Nurul Huda, 2012). Menurut (Kotler dan Keller, 2009), perilaku konsumen itu sendiri dipengaruhi oleh beberapa faktor diantaranya faktor sosial seperti kelompok acuan yaitu kelompok yang terdiri dari semua kelompok yang memiliki pengaruh langsung atau tidak langsung terhadap perilaku orang tersebut.
Dari kelompok acuan tersebut, tidak jarang kalangan Mahasiswa menjadikannya faktor Keputusan Pembelian seperti pada handphone atau Smartphone. Hal ini disebabkan, biasanya Mahasiswa membeli handphone atau Smartphone berdasarkan kelompoknya dan juga semata-mata hanya untuk dapat mengimbangi pergaulan dirinya dengan kelompok acuannya. Selain faktor sosial ada faktor pribadi yang berupa faktor usia dan tahap siklus hidup yitu orang membeli barang dan jasa yang berbeda sepanjang hidupnya, untuk usia kalangan Mahasiswa saat ini, mereka lebih cenderung menggunakan atau mengganti-ganti suatu produk atau barang yang meraka gunakan, karena hal itu sesuai dengan usia mereka yang selalu ingin mengikuti perkembangan zaman dan sesuai dengan kebutuhan yang mereka inginkan seperti halnya kemajuan dalam dunia teknologi terutama dalam bidang komunikasi. Meskipun usia serta kelompok acuan bisa dikatakan sebagai faktor dari perilaku konsumen akan tetapi pekerjaan dan lingkungan ekonomi juga dapat menjadi indikasi ketika seorang konsumen akan memutuskan untuk melakukan pembelian atas suatu produk.

Dilihat dari kalangan Mahasiswa sendiri pola konsumsi mereka biasanya disesuaikan dengan kubutuhannya seharihari baik dari pergaulan atau dari kebutuhan yang mendukung kegiatan mereka sebagai seorang Mahasiswa. Kemudian dilihat dari lingkungan ekonominya seorang Mahasiswa rata-rata belum memiliki penghasilan sendiri, namun masih menggandalkan uang saku ataupun dari pemberian orang tua (dalam Kurnia Akbar, 2013).

\section{RUMUSAN MASALAH}

1. Apakah pengaruh Country of Origin terhadap Keputusan Pembelian Smartphone di Universitas Borneo Tarakan?

2. Apakah pengaruh Brand Image terhadap Keputusan Pembelian Smartphone di Universitas Borneo Tarakan? 


\section{TUJUAN PENELITIAN}

1. Untuk mengetahui pengaruh Country of Origin terhadap Keputusan Pembelian Smartphone di Universitas Borneo Tarakan.

2. Untuk mengetahui pengaruh Brand Image terhadap Keputusan Pembelian Smartphone di Universitas Borneo Tarakan.

\section{TINJAUAN PUSTAKA}

\section{$\underline{\text { Landasan Teori }}$}

Country of Origin adalah seluruh bentuk persepsi konsumen atas produk dari sebuah negara tertentu berdasarkan persepsi konsumen sebelumnya akan kelebihan dan kekurangan produksi serta pemasaran negara tersebut (Roth and Romeo, 1992 dalam Permana, 2013).

Citra merek (Brand Image) merupakan representasi dari keseluruhan persepsi terhadap merek dan dibentuk dari informasi dan pengalaman masa lalu terhadap merek itu. Citra terhadap merek berhubungan dengan sikap yang berupa keyakinan dan preferensi terhadap suatu merek. Konsumen yang memiliki citra yang positif terhadap suatu merek, akan lebih memungkinkan untuk melakukan pembelian. (Setiadi, 2003). Karena itu sikap dan tindakan konsumen terhadap suatu merek sangat ditentukan oleh citra merek tersebut.

Menurut Kotler dan Amstrong (1999), keputusan membeli konsumen adalah membeli merek yang disukai. Konsumen akan melakukan sebuah keputusan dalam membeli sebuah produk yang sesuai dengan harapan dan kebutuhannya.

Kerangka Pemikiran

Berdasarkan pemaparan kajian pustaka, maka disusunlah kerangka pemikiran sebagai berikut :

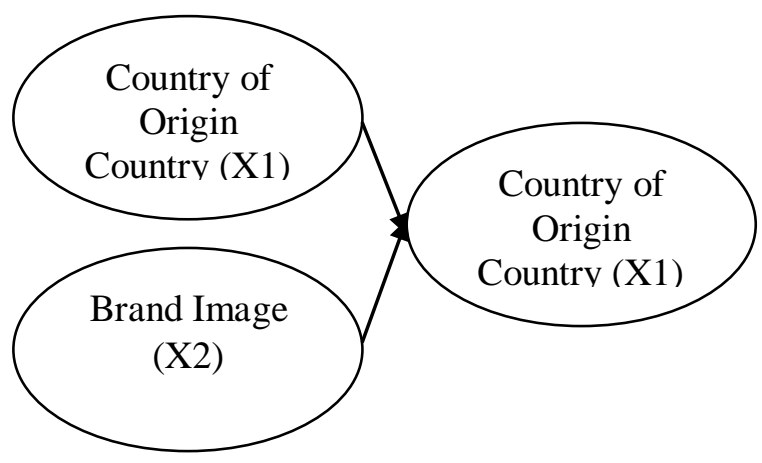

Gambar 1 Kerangka Pemikiran

$\underline{\text { Hipotesis }}$

Berdasarkan pada landasan teori dan kerangka pemikiran tersebut, hipotesis yang diajukan dalam penelitian ini adalah sebagai berikut :

H1: Diduga Country of Origin berpengaruh terhadap keputusan pembelian Smartphone di Universitas Borneo Tarakan.

$\mathrm{H} 2$ : Diduga Brand Image berpengaruh terhadap keputusan pembelian Smartphone di Universitas Borneo Tarakan.

\section{METODOLOGI PENELITIAN}

\section{$\underline{\text { Populasi }}$}

Menurut Sugiyono (2013) populasi adalah wilayah generalisasi yang terdiri dari objek/subjek yang mempunyai kualitas dan karakteristik tertentu yang ditetapkan oleh peneliti untuk dipelajari dan kemudian ditarik kesimpulannya. Populasi dalam penelitian ini adalah seluruh mahasiswa yang masih aktif di Universitas Borneo Tarakan.

Khususnya mahasiswa yang menggunakan martphone yang berasal dari beberapa negara.

$\underline{\text { Sampel }}$

Menurut Sugiyono (2013) sampel adalah bagian dari jumlah dan karakteristik 
yang dimiliki oleh populasi tersebut. Dalam penelitian digunakan metode non-probability sampling dimana Menurut Sugiyono (2001) nonprobability sampling adalah teknik yang tidak memberi peluang/kesempatan yang sama bagi setiap unsur atau anggota populasi untuk dipilih menjadi sampel. Teknik pengambilan sampel yang digunakan adalah metode pengambilan sampel bertujuan (purposive sampling),

Sugiyono (2001) menyatakan bahwa sampling purposive adalah teknik penentuan sampel dengan pertimbangan tertentu. Dalam penentuan sampel ini hanya diginakan beberapa sampel saja mengingat jumlah populasi dari sampel terlalu besar, sehingga peneliti tidak mungkin mempelajari semua yang ada pada populasi, hal itu dikarenakan keterbatasan dana, tenaga dan waktu. Sehingga penentuan sampel dilakukan dengan cara memilih sampel yang dapat mewakili populasi tersebut.

\section{Data Primer}

Kata primer adalah lawan kata dari sekunder, dimana artinya asli atau utama atau secara langsung dari sumberdayanya. Jadi pengertian data primer adalah data asli yang dikumpulkan oleh periset untuk menjawab masalah riset secara khusus (Istijanto, 2005).

\section{Data Sekunder}

Data sekunder adalah data yang diperoleh secara tidak langsung atau melalui perantara. (Danang Sunyoto, 2012) data yang merupakan data publikasi yang dikumpulkan tidak hanya untuk keperluan satu rist tertentu saja.

\section{Metode Pengumpulan Data}

Metode pengumpulan data yang digunakan dalam penelitian ini adalah metode survei dengan alat bantu kuesioner. Teknik pengumpulan data dengan kuesioner merupakan teknik pengumpulan data yang dilakukan dengan cara memberi seperangkat pertanyaan atau pernyataan tertulis kepada responden untuk dijawab (Sugiyono, 2013).

Skala Likert dalam penelitian ini adalah skala yang berisi 5 tingkat preferensi jawaban dengan pilihan sebagai berikut :

1. Sangat setuju (SS) dengan nilai 5.

2. Setuju (S) dengan nilai 4.

3. Netral (N) dengan nilai 3.

4. Tidak setuju (TS) dengan nilai 2 .

5. Sangat tidak setuju (STS) dengan nilai 1.

\section{HASIL PENELITIAN}

\section{$\underline{\text { Uji Validitas }}$}

Menurut (Ghozali, 2011). Uji validitas dilakukan dengan membandingkan nilai $r$ hitung dengan nilai $r$ tabel untuk degree of freedom $(d f)=n$ (jumlah responden) $-k$ (jumlah variabel independen) dengan alpha 0,05 .

Jika $r$ hitung lebih besar dari $r$ tabel dan nilai $r$ positif, maka butir atau pertanyaan tersebut dikatakan valid. Untuk hasil analisis dapat dilihat pada output uji reliabilitas pada bagian correted item total correlation.

Dalam penelitian ini level signifikasi $(\alpha)=0,05$ (two tailed) dan derajat kebebasan (df) $=100-2=98$. Jadi nilai yang dipersyaratkan adalah sebesar 0,165 (Ghozali, 2011). Berdasarkan hasil uji validitas terhadap masing-masing indikator menunjukkan nilai diatas yang dipersyaratkan, yaitu $>0,165$ sehingga semua item ini dikatakan valid dan dapat diproses dalam pengujian lanjutan.

\section{Uji Reliabilitas}

Uji reliabilitas digunakan untuk mengukur suatu kuesioner yang merupakan indikator variabel atau konstruk. Suatu kuesioner dikatakan reliabel atau handal jika jawaban seseorang terdapat pernyataan adalah konsisten atau stabil dari waktu kewaktu. Nilai reliabilitas variabel ditunjukkan oleh koefisien cronbach alpa $>0,70$ (Ghozali, 2011).

Berdasarkan uji reliabilitas dapat diketahui bahwa seluruh variabel yang 
digunakan menurut kriteria (Ghozali, 2011) dinyatakan reliabel, karena memiliki nilai Cronbach Alpa lebih besar dari 0,70.

Uji Multikolinieritas

Uji multikolinieritas bertujuan untuk menguji apakah model regresi ditemukan adanya korelasi diantara variabel bebas. Cara untuk mendeteksi adanya multikolinieritas adalah dengan melihat besarnya Tolerance Values dan Variance Inflation Factor (VIF). Variabel yang menyebabkan multikolinieritas dapat dilihat dari nilai tolerence < 0,10 dan VIF > 10 (Ghozali, 2011).

Berdasarkan hasil pengujian ultikolinieritas, hasil perhitungan nilai tolerance juga terlihat bahwa tidak ada variabel independen yang memiliki nilai tolerance $<0,10$ yang artinya tidak ada korelasi antara variabel independent. Demikian juga dengan hasil perhitungan nilai VIF (Variance Inflation Factor), dari kedua variabel independen yang diuji tidak ada nilai VIF (Variance Inflation Factor) yang > 10, maka dapat disimpulkan bahwa tidak ada multikolinieritas antara variabel independent dalam model regresi.

\section{Uji Heteroskedastisitas}

Uji heteroskedastisitas ini bertujuan untuk menguji apakah dalam model regresi terjadi ketidaksamaan varians dari residual satu pengamatan ke pengamatan lain. Ghozali (2011). Berdasarkan hasil pengujian asumsi klasik Scatterplot bahwa titik-titik menyebar secara acak serta tersebar diatas maupun dibawah angka 0 pada sumbu y, serta tidak mempunyai pola yang jelas atau tidak membentuk suatu pola, Untuk itu dapat disimpulkan bahwa tidak terjadi heteroskedastisitas pada model regresi, sehingga model regresi layak dipakai sebagai alat prediksi.

\section{Uji Normalitas}

Menurut Ghozali (2011) uji normalitas bertujuan untuk menguji apakah variabel terikat dan variabel bebas dalam model regresi mempunyai distribusi normal atau tidak. Model regresi yang baik adalah yang memiliki distribusi normal atau mendekati normal.

Metode yang dipakai untuk mengetahui kenormalan model regresi adalah One Sample Kolmogorov-Smirnov Test. Distribusi data dinyatakan normal apabila nilai $\mathrm{p}$ dari One Sample Kolmogorov- Smirnov Test > 0,05, dan sebaliknya.

Hasil uji Kolmogrov-Smirnov menunjukkan bahwa nilai KolmogrovSmirnov adalah 0,066 dan signifikan pada nilai Asymp.Sig.(2-tailed) > tingkat alpha yang ditentukan 5\% (0,05), yakni 0,200 > 0,05 maka dapat disimpulkan bahwa model regresi memenuhi asumsi normalitas yang berarti data distribusi normal.

Pengujian distribusi normal juga dilakukan dengan cara melihat histogram yang membandingkan data observasi dengan distribusi yang mendekati normal. Disamping itu digunakan normal probability plot yang membandingkan distribusi kumulatif dari data yang sesungguhnya dengan distribusi kumulatif dari data distribusi normal. Jika distribusi normal, maka garis yang menggambarkan data sesungguhnya akan mengikuti garis diagonalnya.

Adapun hasil uji normalitas grafik histogram dan grafik normal plot yang tersaji diatas dapat disimpulkan bahwa grafik histogram memberikan pola distribusi yang normal. Sedangkan pada grafik normal plot terlihat titik-titik menyebar diatas garis diagonalnya. Kedua grafik ini menunjukkan bahwa model regresi layak digunakan karena memenuhi asumsi normalitas.

\section{Analisis Regresi Linier Berganda}

Analisis regresi berganda untuk menghitung besarnya pengaruh secara kuantitatif dari suatu perubahan kejadian (variabel $X$ ) terhadap kejadian lainnya (variabel Y). Dalam penelitian ini, analisis regresi berganda berperan sebagai teknik 
statistik yang digunakan untuk menguji ada tidaknya pengaruh Country of Origin (X1) dan Brand Image ( $\left.\mathrm{X}_{2}\right)$ terhadap keputusan pembelian (Y). Persamaan regresi linier berganda adalah sebagai berikut (Ghozali, 2011):

$\mathbf{Y}=\mathbf{a}+\mathbf{b}_{1} X_{1}+\mathbf{b}_{2} X_{2}+e$

Keterangan :

$\mathrm{Y}=$ Variabel dependen ( Keputusan pembelian)

A = Bilangan konstanta

$\mathrm{b}_{1}, \mathrm{~b}_{2},=$ Koefisien garis regresi

$\mathrm{X}_{1}, \mathrm{X}_{2}=$ Variabel independen

(Country of Origin dan Brand Image)

$\mathrm{E} \quad=$ Variabel penggangu (error)

$Y=6,112+-0,093 X_{1}+0,350 X_{2}+e$

Dari persamaan regresi tersebut dapat dijelaskan seperti berikut ini :

1. Bilangan konstanta $(a)=6,112$ Artinya apabila Country of Origin (X1) dan Brand Image (X2) sama dengan nol (tidak ada perubahan), maka Keputusan Pembelian (Y) sebesar 6,112.

2. Koefisien regresi Country of Origin (b1) $=-0,093$ Koefisien regresi sebesar 0,093 artinya, jika Country of Origin (X1) sebesar 1 satuan, maka Keputusan Pembelian sebesar -0,093. Dalam hal ini faktor lain dianggap konstan.

3. Koefisien regresi Lingkungan Kerja (b2) $=0,350$ Koefisien regresi sebesar 0,350 artinya, jika Brand Image (X2) sebesar 1 satuan, maka Keputusan Pembelian sebesar 0,350. Dalam hal ini faktor lain dianggap konstan.

\section{Uji Hipotesis (Uji t)}

Menurut Ghozali (2011), uji t digunakan untuk menentukan apakah variabel independen $(X)$ berpengaruh secara parsial atau sendiri-sendiri terhadap variabel dependen (Y). Nilai thitung diperoleh dari hasil output SPSS sedangkan ttabel diperoleh dari tabel statistik dengan melihat nilai signifikansi (a) dan degree of freedom.
Dengan pengambilan keputusan sebagai berikut :

1. Jika thitung $>$ tabel, maka hipotesis nol $\left(\mathrm{H}_{0}\right)$ ditolak dan $\mathrm{Ha}$ diterima yang artinya variabel Country of Origin dan Brand Image tersebut secara parsial berpengaruh terhadap nilai profitabilitas Keputusan Pembelian.

2. Jika thitung $<$ tabel, maka hipotesis nol $\left(\mathrm{H}_{0}\right)$ diterima dan menolak

Ha, artinya variabel Country of Origin dan Brand Image tersebut secara parsial tidak berpengaruh terhadap nilai profitabilitas Keputusan Pembelian. Dalam penelitian ini level signifikansi $(\alpha)=0,05$ (two tailed) dan degree of fredom $(\mathrm{df})=\mathrm{n}$ (jumlah responden) - $\mathrm{k}$ (jumlah variabel independent $)=100-2=98$. Jadi nilai yang dipersyaratkan ttabel adalah sebesar 1,661 (Ghozali, 2011).

Hasil pengujian hipotesis masingmasing variabel dapat diuraikan sebagai berikut:

$\mathrm{H}_{1}$ : Country of Origin tidak berpengaruh signifikan terhadap Keputusan Pembelian. Nilai nominal antara variabel Country of Origin terhadap variabel Keputusan Pembelian menunjukkan hasil nilai thitung = 1.230 lebih kecil dari yang dipersyaratkan yaitu, tabel $=1,661$ dengan taraf signifikan sebesar 0,05. Hal ini berarti hipotesis 1 tidak terdukung.

$\mathrm{H}_{2}$ : Brand Image berpengaruh signifikan terhadap Keputusan Pembelian. Nilai nominal antara variabel Brand Image terhadap variabel Keputusan Pembelian menunjukkan hasil nilai thitung $=6,152$ lebih besar dari yang dipersyaratkan yaitu, tabel $=$ 1,661 dengan taraf signifikan sebesar 0,05. Hal ini berarti hipotesis 2 terdukung.

\section{$\underline{\text { Pembahasan }}$}

Tujuan dalam penelitian ini adalah untuk mengetahui apakah variabel Country of Origin (X1) dan Variabel Brand Image (X2) memiliki pengarus secara parsial terhadap Keputusan Pembelian (Y), berikut ini diuraikan pembahasan mengenai pengaruh dari kedua variabel bebas tersebut 
terhadap Keputusan Pembelian sebagai berikut :

Pembahasan Country of Origin Terhadap KeputusanPembelian.

Country of Origin adalah seluruh bentuk persepsi konsumen atas produk dari sebuah negara tertentu berdasarkan persepsi konsumen sebelumnya akan kelebihan dan kekurangan produksi serta pemasaran negara tersebut (Roth and Romeo, 1992 dalam Permana, 2013). Country of Origin adalah elemen pemasaran yang penting dan diketahui mempengaruhi perilaku serta persepsi konsumen. Ketika konsumen hanya mempunyai informasi dimana lokasi suatu produk dihasilkan, maka dalam pengambilan keputusan pembelian akan dipengaruhi oleh persepsi konsumen akan negara tersebut (Sutanto dan Winata, 2012).

Berdasarkan hasil penggujian hipotesis pertama terlihat bahwa variabel Country of Origin memiliki nilai signifikan 0,222 tahapan penggujian menggunakan tingkat kesalahan 5\% $(0,05)$, dengan demikian terlihat bahwa nilai signifikan 0,222 lebih besar dari alpa 0,05 dan maka keputusanya adalah $\mathrm{Ho}$ di terima dan $\mathrm{Ha}$ ditolak. Jadi dapat disimpulkan bahwa Country of Origin tidak berpengaruh signifikan terhadap Keputusan Pembelian Smartphone di kalangan Mahasiswa Universitas BorneoTarakan.

Adapun alasan yang dapat disampaikan mengapa variabel Country of Origin tidak berpengaruh terhadap keputusan pembelian Smartphone di kalangan Mahasiswa Universitas Borneo Tarakan, karena Country of Origin dalam penelitian ini merupakan persepsi konsumen terhadap negara asal Smartphone yang mahasiswa gunakan. Konsumen melakukan pembelian bukan berdasarkan darimna negara asal Smartphone tersebut, melaikan karena faktor-faktor lain. Konsumen bisa dipengaruhi dengan harga Smartphone yang terjangkau, kualitas Smartphone yang baik, merek Smartphone. Sehingga konsumen tidak mempertimbangkan persepsi atas negara asal samrtphone tersebut, sehingga kondisi tersebut tidak mempengaruhi konsumen untuk membeli Smartphone.

Hasil penelitian ini tidak sejalan dengan hasil penelitian terdahulu yang dilakukan oleh Febrianto dan Wijayati (2014) dengan judul Pengaruh Country of Origin, Brand Image, dan preceived quality terhadap keputusan pembelian sepeda motor honda beat di Kota Denpasar. Hasil penelitian ini menunjukan bahwa variabel Country of Origin berpengaruh positif dan signifikan terhadap keputusan pembelian sepeda motor Honda Beat di Kota Denpasar.

\section{Pembahasan Brand Image}

Terhadap Keputusan

Pembelian

\section{Citra merek (Brand Image)} merupakan representasi dari keseluruhan persepsi terhadap merek dan dibentuk dari informasi dan pengalaman masa lalu terhadap merek itu. Citra terhadap merek berhubungan dengan sikap yang berupa keyakinan dan preferensi terhadap suatu merek. Konsumen yang memiliki citra yang positif terhadap suatu merek, akan lebih memungkinkan untuk melakukan pembelian. (Setiadi, 2003).

Berdasarkan hasil penggujian hipotesis kedua terlihat bahwa variabel Brand Image memiliki nilai signifikan 0,000 tahapan penggujian menggunakan tingkat kesalahan $5 \% \quad(0,05)$, dengan demikian terlihat bahwa nilai signifikan 0,000 lebih kecil dari alpa 0,05 dan maka keputusanya adalah Ho ditolak dan $\mathrm{Ha}$ diterima. Jadi dapat disimpulkan bahwa Brand Image berpengaruh signifikan terhadap Keputusan Pembelian Smartphone di kalangan Mahasiswa universitas Borneo Tarakan.

Terjadinnya pengaruh yang signifikan dari Brand Image terhadap Keputusan Pembelian Smartphone ikalangan Mahasiswa Universitas Borneo Tarakan, disebabkan karena Brand Image faktor yang timbul dari persepsi konsumen yang menciptakan Keputusan Pembelian Smartphone di kalangan Mahasiswa 
Universitas Borneo Tarakan, hal ini disebabkan karena Brand Image di pengaruhi oleh merek yang mudah diingat, harga, kualitas, status sosial, reputasi merek. Hasil penelitian ini sejalan dengan hasil penelitian terdahulu yang dilakukan oleh Febrianto dan Wijayati (2014) dengan judul Pengaruh Country of Origin, Brand Image, dan preceived quality terhadap keputusan pembelian sepeda motor honda beat di Kota Denpasar. Hasil penelitian ini menunjukan bahwa variabel variabel Brand Image berpengaruh positif dan signifikan terhadap keputusan pembelian sepeda motor Honda Beat di Kota Denpasar.

\section{KESIMPULAN}

Dalam penelitian maka dapat di ambil beberapa kesimpulan. Peneltian ini dilakukan untuk mengetahui Pengaruh Country of Origin, Brand Image Terhadap Keputusan Pembelian Smartphone Di Universitas Borneo Tarakan (studi kasus pada Mahasiswa/i Universitas Borneo Tarakan). Berdasarkan hasil penelitian dan pembahasan model hipotesis yang diajukan, maka dapat ditarik kesimpulan sebagai berikut :

1. Faktor Country of Origin Tidak berpengaruh positif dan signifikan terhadap Keputusan Pembelian Smartphone (Studi Kasus Pada Mahasiswa/i Universitas Borneo Tarakan).

2. Faktor Brand Image berpengaruh positif dan signifikan terhadap Keputusan Pembelian Smartphone (Studi Kasus Pada Mahasiswa/i Universitas Borneo Tarakan).

\section{SARAN}

Berdasarkan hasil dan kesimpulan dalam penelitian ini, berikut adalah beberapa saran yang dapat penulis sampaikan :

1. Berdasarkan hasil penelitian diketahui bahwa penilaian responden terhadap smartphone pada variabel Country of Origin berpengaruh negatif dan tidak signifikan terhadap keputusan pembelian.Sedangkan variabel brand image terbukti memiliki pengaruh yang signifikan dan positif terhadap keputusan pembelian. Sehingga perusahaanperusahaan smartphone diharapkan dapat terus meningkatkan dan memaksimalkan variabel brand image dengan cara, memperhatikan atribut-atribut teknis dan faktor fisik seperti: desain kemasan yang menarik, logo yang mudah diingat, nama merek mudah di ingan dan disebutkan, fungsi dan kegunaan produk yang makin meningkat, serta iklan yang menarik calon konsumen untuk membeli produk smartphone supaya konsumen dapat memutuskan untuk membeli produk smartphone tersebut dan kesan memiliki kesan baik terhadap produk tersebut setelah membeli smartphone tersebut.

2. Dalam penelitian ini mengguakan metode Purposive Sampling Sugiyono (2001) menyatakan bahwa sampling purposive adalah teknik penentuan sampel dengan pertimbangan tertentu. Populasi dalam penelitian ini tidak diketahui. Sehingga disarankan untuk peneliti selanjutnya menggunakan metode lainnya dan teknik pengambilan sampel yang berbeda agar dapat menghasilkan variasi dalam penelitian.

3. Bagi penelitian selanjutnya disarankan untuk mengembangkan dengan menambahkan beberapa variabel lain seperti intensi pembelian, minat beli, brand image global, yang lainya yang lebih spesifik untuk memperkuat pengaruh atau hubungan antara variabel independen dan dependen. Karena dalam hasil penelitian ini bahwa salah satu variabel independen dalam penelitian ini yaitu Country of Origin tidak mempunyai pengaruh yang signifikan terhadap variabel dependen yaitu Keputusan Pembelian. 


\section{DAFTAR PUSTAKA}

Abdi, Tedja. 2009. Pengaruh Brand Image dan Country of Origin Terhadap Kepuasan dan Loyalitas Kondumen Pada Produk TV Samsung Di Kota Surabaya, Jurnal Manajemen.

Amstrong dan Kotler. 1999. Prinsip-prinsip Pemasaran. Erlangga : Jakarta.

Cordell, Victor, V. 1992. "Effect of Consumer Preferences for Foreign Sourced Products". Journal of International Business Studies. Second Quarter: pp 251 269.

Febrianto. Wijayati. 2014. Pengaruh country of Origin, brand image, dan preceived quality terhadap keputusan pembelian sepeda motor honda beat di Kota Denpasar.

Ghozali, Imam. 2011. Aplikasi Analisis Multivariate Dengan Program SPSS. Universitas Diponegoro press. Semarang. J.E,Sutanto dan Winata, Ryan. Hartanto.2012. Pengaruh Merek, Asal Negara, Kepercayaan Terhadap Perusahaan Dan Harga Terhadap Keputusan Pembelian Produk Hair Extension di Surabaya. Jurnal Ekonomi Bisnis Volume 17, No. 1, April 2012.

Hananto, Kitto. 2015. Pengaruh Brand Image dan Country of origin Image Terhadap Minat Pembelian Iphone. Jurnal Manajemen. Vol. 2, No. 2 : 13- 22.

Hong, S.T. and Wyer, R.S. 1989. "Effects of Country of Origin and Product Attribute Information on Product Evaluation: An Information Processing Perspective". Journal of Consumer Research, Vol. 16 No.2, pp. 175-87.

Huda, Nurul. 2012. Pengaruh Brand Image Terhadap keputusan Pembelian Motor Scuter Matic Yamaha Di Makassar. Skripsi. Fakultas
Ekonomi dan Bisnis Universitas Hassanudding. Makassar.

Istijanto. 2005. Aplikasi Praktis Riset Pemasaran. Penerbit PT Gramedia Pustaka Utama : Jakarta.

Kompas.com. 2014. Indonesia Pasar Smartphone terbesar di Asia Tengggarahttp://tekno.kompas.co $\mathrm{m} / \mathrm{read} / 014 / 06 / 15 / 1123361 /$ indone sia.pasar.smartphone.terbesar.di. as ia.tenggara. E-Marketer. Two Billion Consumers Worldwide Smartphones.2016.http://www.em arketer.com/Arti cle/2-BillionConsumersWorldwideSmartphone s-by-2016/1011694. Diakses pada tanggal Senin, 25 April 2016.Pukul 18.56.

Kotler, Philip dan Kevin Keller. 2009. Manajemen Pemasaran. Jilid I. Edisi Ke-13. Diterjemahkan Oleh Bob Sabran. Jakarta : Erlangga.

Permana, Magyar Slamet. 2013. Pengaruh Country Of Origin, Brand Image, Dan Persepsi Kualitas Terhadap Intense Pembelian. Kertas Kerja. Universitas Kristen Satya Wacana. Salatiga.

Rangkuti, Freddy. 2004. Manajemen Persediaan: Aplikasi di Bidang Bisnis. Jakarta: Grafindo Persada.

Roth, Martin S., Jean B. Romeo. .1992." Matching Product Category and Country Image Perceptions: A Framework for Managing Country of Origin effects". Journal of International Busines Studies. Third Quarter: pp 477-495.

Setiadi, Nugroho. 2003. Perilaku Konsumen. Penerbit: Kencana Jakarta.

Simamora, Bilson. 2004. Panduan Riset Perilaku Konsumen. Jakarta: Gramedia Pustaka Umum.

Sugiyono. 2013. Statistika Untuk Penelitian. Alfabeta : Bandung.

Sugiyono dan Wibowo, Eri. 2001. Statistika Penelitian. Cetakan 1. Alfabeta : Bandung. 
Sunyoto, Danang. 2012. Konsep Dasar Riset

Pemasaran \& Prilaku Konsumen.

CAPS Yogyakarta.

Wikipedia. Ponsel Cerdas. 2016.

https://id.wikipedia.org/wiki/P

onsel_cerdas. 